ISSN: $2576-2141$

\title{
Accounts and Thoughts of Overage Children: A Qualitative Study on the Physical and Emotional Environment of Preschools in Ibadan, Nigeria
}

\author{
Iyanuoluwa Emmanuel Olalowo ${ }^{1}$ \\ University of Ibadan, Nigeria
}

\begin{abstract}
Children are brought up in diverse yet specific physical and social environments formally regarded as preschool centres; they are engaged from preschool age in activities where their development is affected by an array of social factors. Some of these factors are natural while some are measures of external circumstances, which if neglected may endanger proper child care, learning and development at the early years. As the child's age stands as one of such natural factors that can't be tampered with, literatures from Nigeria researches mostly give account of it from either an underage or age appropriate perspective, little is known or revealed on the state of overage children in preschools. With developmentally appropriate practices in mind, this study therefore investigated the experiences of overage children in preschool centres with respect to the suitability of their physical environment, peer interaction as well as the kind of interaction between these children and their teachers. In answering the research question, $a$ qualitative research design was staged. The qualitative data collection adopted a phenomenological approach where experiences of respondents and other features were examined qualitatively. Twelve (12) overage pupils from 6 preschool centres in Ibadan were interviewed through conversational key informant interview. Interviews were recorded, transcribed and were presented alongside field notes from research assistants using a thematic analysis. Findings had it that children in rural setting were of the view that their teachers do not interact with them so well, urban pre-primary schools children claimed that their teachers played with them as most of them also have nick names given to them by their teachers. Caregivers as well as preschool administrators should therefore ensure that provisions and daily activities within the school system is geared towards the development of the whole child such that no child is left behind regardless educational dilatory experience.
\end{abstract}

KEYWORDS: Overage Preschool Children, Peer Interaction, Physical Ambience, Preschool, Teacher-child Interaction.

\section{Introduction}

Early childhood has a strategic place in the life of every individual. Experiences, environments and relationships that children have in the early years, sets the stage for their lifelong development. Getting it right at these early years of life for the child is very important for any domain of development to succeed and form into a functional state. Insofar, there had been no other formal structure being set up to enable this formation other than the preschool centres where children are brought up in diverse yet specific physical and social environments.

\footnotetext{
${ }^{1}$ E-mail: iyanu4rabbi@gmail.com
} 
The preschool is vital to a child, parents and society because it permits smooth transition from home to school; aiding the child to have easy interaction with other people outside his immediate family members.

Generally, one of the philosophies of the Nigerian education system as mentioned in the National Policy on Education is based on the development of the individual into a sound and effective citizen (Federal Republic of Nigeria, 2013). The document went on to establish the objectives of 1-year pre-school education all of which, without barrier of any individual differences, summarily addresses the holistic development of the child. The operational objectives of pre-primary education as stated in the National Policy of Education (FRN, 2013) are spelt out to include;

\section{effecting a smooth transmission from the home to the school; Preparing the child for the primary level of education; Providing adequate care and supervision for the children while their parents are at work; Inculcating in the child the spirit of enquiry and creativity through the exploration of nature and environment, art, music and playing with toys, etc; Develop a sense of co-operation and team spirit; Inculcating social norms; Learn good habits, especially good health habits and Teaching rudiments of numbers, letters, colours, shapes, forms etc. through play.}

The rationale for this paper is centred on the premise that, having put all the aforementioned together, coupled with the fact that the school being a medium through which formal education is delivered, the preschool is placed in a position of one of the institutions with the responsibility of raising a whole-child which in Yoruba society is referred to as omo to dape meaning an all-round developed child (Salami, 2018).

An essential environmental factor worthy of consideration in lieu of the child's total development is that which appeals to the social and emotional development characterised mainly by human features/activities. This includes such factors as the kind of relationship established between the caregiver, teacher or gardener and the child (teacher-child interaction), the teachers' personal orientation of the child (Al-Badou et al., 2020), the interaction flow that goes on between a preschool child and his/her peers. These contribute to what could be regarded as the emotional ambience within the school system. These factors may even be more important than the factors of direct teaching and delivery of instructions as not even the most deserved act of teaching compensate for an impoverished aura of affective acceptance to be experienced by the child. As pupils go to school every week, the two major aspects of their day to day lives are their relationships with their teachers and with their peers as they also learn to be independent and strong through building positive relationships (UK Department for Education, 2017)

The term teacher-child relationship and possibly the concept of teachers' orientation of their pupils is generally a debatable one which covers issues such as the influence of teachers on the behaviour, intellectual and social development of the children, the contributions the teacher makes to the mental development and adjustment of the children, the teachers' likes and dislikes with regards to their pupils and the effect of the teachers' productive daily contact with the children (Carothers \& Parfit, 2017; Gumus et al., 2019). According to McGuey and Moore (2016), it is important to see the child as a whole and to place building relationships before the curriculum, as the quality of a teacher-child relationship is the foundation of a deeper learning experience.

The emotional ambience is considerably affected by the kind of relationship which a teacher creates and establishes with the children. Good relationships between the teacher and the children are vitally important in the give and take of the school environmental influences; where such exists; there is less likelihood of difficulties to arise when trying to aid the 
development of any domain of the child whether physical, social and emotional, and intellectual. Conversely, especially with overage children, the teacher-child interaction is too formal, resembling a 'master-slave' relationship; communication being from teacher to pupil with distant interaction, creating a wide social gap between the teachers and the pupils (Salami \& Folaranmi, 2015). A central organ of effective teacher-child relationship is the teacher's "respect for persons"- this has to do with operating with the children as "individuals" rather than a "class" as well as valuing their personal characteristics. This concept of respect for the children individually creates an accommodating consciousness for overage children.

Although, the concept of overage children in pre-school may appear exclusive in the Nigerian context, it is an often-silenced educational challenge, which could make or mar the child's development at virtually all levels of education especially at the pre-primary level. The Cambridge Dictionary of language defined it as a state of being older than a particular age and therefore no longer opportune to do some things or have some particular experiences. In the view of Knevals (2014), overage children in the education parlance was regarded as a high-risk student who "is over traditional school-age for his/her grade level and lacks adequate credit hours for his/her grade level. In the context of the Nigerian preschool, an overage child is a member of a class whose age is beyond the stipulated 5-6years age limit for the one-year preprimary education.

Often-silenced by the assertion that the idea of overage children in schools are mostly a lacuna obtainable in war-recovering countries, the problem has persisted conveniently in Nigerian schools both in the rural and urban communities, most especially in cases where education is either made low-cost, free and/or under-supervised. The more fundamental drawback of not focusing on overage children is that it relegates early childhood developmentally age and individual appropriate practises to a general classroom category and detracts attention from securing a long-term, sustainable considerations from early childhood practitioners.

The position of Salami (2016) that children of different ages were given admission and were put into the same class in most cases substantiates the submission of a global research finding which showed that the decreasing status of overage children in schools has not left the subject-matter in a zero state. In a report prepared on International Standard Classification of Education (ISCED), the national percentage of overage children in primary schools in Nigeria was estimated at $23 \%$ for children who are 2 years above the regular class age and $44 \%$ for children who are 3years above the regular class age. The table below presents the report of few countries and the position of Nigeria in the extent of overage children within 2 and 3 years post appropriate age limit.

Assigning pupils of various statuses into classrooms as addressed by Ezewu (1986) in Henning et al. (2018) when he observed that grouping in any school in Nigeria is accidental, that is, pupils have been assigned to the class either by the reason of age, sex or ability. Oduolowu (2019) asserted that grouping of primary school pupils into classes according to age is the most common practise in Nigeria. This practice, however, if not securitized, threatens the kind of developmentally appropriate practise the child would be exposed to. The children are bound to face some conflicts in their minds either to be active in class and or to be avid in interacting with other children. Such a situation as this requires a systematic approach that should be of interest to everyone working with the children.

On the matter of peer-interaction, (which connotes the relationship status that exists between overage children and their peers as well as regular aged children), children generally and specifically overage children's perception of themselves will, by default, be a determinant in motivating them to relate effectively with their peers and teachers through which their socioemotional competencies are developed. These interactions eventually become an important factor of their mental health status, that is, the development of their cognition, (Amosun, 2012; Kaliska, 2019). In a more recent study, (Amosun, 2019) observed that such children who have 
found themselves in pre-primary classes tend to be either selective in their choice of interaction and relationship or are faced with the consequences of peers' selectivity of relationship and interaction. A close observation of primary school pupils in Nigeria shows that there are children, who in their classes are apparently not accepted by the other class members and this non-acceptance is either manifested overtly or covertly. Any whither, the child who is not accepted is aware of the absence of acceptance.

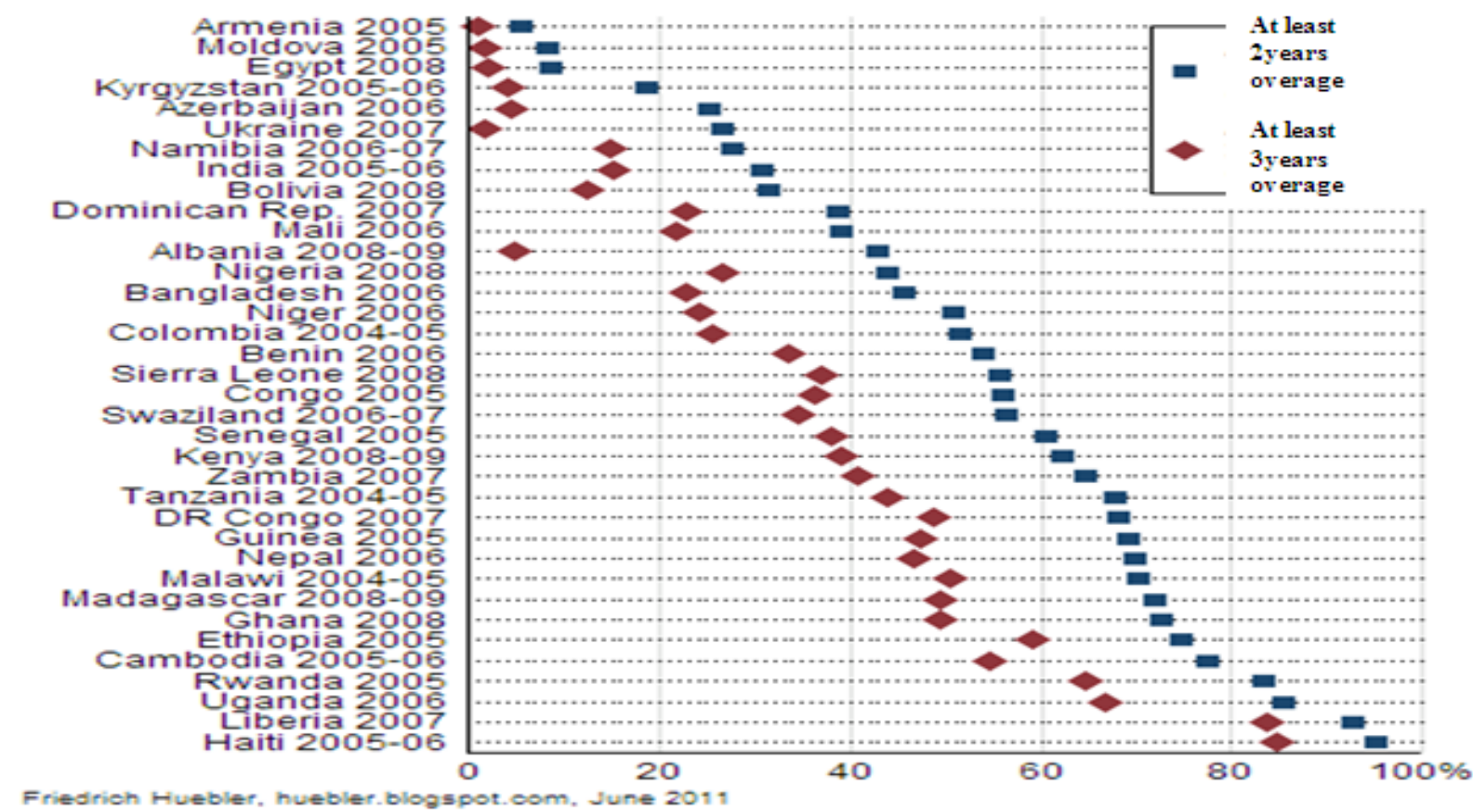

Figure 1. Report of Overage Children in Primary Schools of Selected Countries Note. From UNESCO Institute for Statistics (2012).

Preschool which happens to be the four walls where all the earlier discussed issues are homed also faces challenges of availability of appropriate physical resources. More so, preschool environments, classrooms, provisions of infrastructural materials are essential for meaningful interaction. The physical ambience must be conducive to facilitate children interaction with their environment to enable them have meaningful experiences. Such infrastructural materials have a set of developmental appropriate practises to be considered such as their class appropriateness, cultural appropriateness and most importantly their age appropriateness.

\section{Literature Review}

According to the Lesotho Fast Track Initiative assessment report (Fast Track Initiative, 2013) overage school attendance is common in sub-Saharan Africa but also occurs in other regions. In African parlance, the problem of overage children can be linked to several reasons. An instance being in conflict situations where children have to migrate to neighbouring communities to either continue their education, depend on makeshift community schools or temporarily stop their education. As a result, especially at the primary education level, overage enrolment has continued to remain a post-insurgency legacy (Advocates for Children of NewYork, 2008; Akpan, 2018; Dallas Morning News, 2010; SECC, 2008).

Overage children are more vulnerable and at greater risk of dropping out either because they get dissuaded for reasons which include lack of acceptability within the school system, lack of tolerance among peers as most of them are sometimes with emotionally destructive 
names such as “àgbààyà (a useless old fellow), adàgbà-mádanú (one who is old but doesn't think). Overriding this, Darvas \& Namit (2016) posited in their research that, it is still better to send children to school even if they are overage. The benefits may not only be measured in education attainment and literacy, but in other skills such as better family health and better attitudes towards educating one's own children.

With regard to the emotional ambience aspect of overage children, daily personal interactions with children are the basic building blocks of the teacher-child interaction (Pennings, et al, 2018). In a generalizability study comparing the framework for teaching and the classroom assessment scoring system among kindergarten teachers in Colombia, it was submitted that teacher's practices have the potential to make a positive contribution to a child's development which is also in corroboration with the findings of another research by (Mantzicopoulos, et al, 2018; Hamre et al., 2014). Towing the same line, some other researchers have found a positive association between teacher-child closeness (one aspect of the teacherchild relationship) and children's social-emotional situational knowledge (i.e., knowledge gained from dealing with certain situations) in both a middle-income preschools and a lowsocio-economic status Head Start (Garner et al., 2014).

Sjoman (2018) in compilation of the thesis on the influence of peer interaction on the link between behaviour difficulties and engagement among children with and without need-for support asserted that peer-to-child interaction and teacher responsiveness were rated lower for these children, both in current time and longitudinally.

In a study conducted by Chepkonga (2017) on the availability and adequacy of learning facilities in public ECDE centres in West Pokot County, where teachers were asked to indicate the extent to which lists of learning facilities were available in their schools, the researcher reported that the available classrooms are in sorry state as some of them are not cemented requiring water to be poured daily to control disease and dust induced illnesses.

The literature reviewed has established that there had been various studies embarked upon in concerns related to some of the identified variables for this study. However there still exists a gap in literature that takes to heart, the account of overage children hence necessitating the study of pre-school overage children's experience with regards to specific school environmental factors.

\section{Case and Methodology}

This study was carried out in Ibadan, the capital city of Oyo State Nigeria. Generally, Ibadan has a total of eleven Local Governments. The Stratified sampling technique was used to divide these local governments into two which covered the urban settlements and rural settlements. Five of the eleven local governments are in Ibadan Metropolis which represented the urban area while the remaining six are local governments around Ibadan metropolis which forms the rural area of Ibadan. Simple random sampling technique was used to select one local government each from the two clusters to serve as the rural and urban location respectively through balloting. The reason for this is to give equal chances of being selected for the local governments in the two clusters. Names of the local governments in the two clusters were wrapped up and placed in two different bowls and the researcher picked one local government from each bowl. Ona-Ara local government was picked to represent the rural while Ibadan North Local Government Area was picked to represent the urban area. The choice of picking the samples from these two settlements was to ensure that the study entertained the realities from both marginalized communities and cities as well.

Three primary schools were purposively selected from the two settlements each to make a total of six schools. The uniform criteria for the selection of these schools are as follows:

a) The school is a public primary school 
b) The school has a preschool centre/section

c) The preschool section has a permanent teacher/caregiver

d) The preschool section has at least one (1) overage child

e) The school must have been in operation for at least 10 years such that it is expected to have good physical resources

Due to the peculiarity of the study, total enumeration was used to select all overage children in the schools selected. Upon these criteria and the guiding foci of this study, the sociodemographic data of the participating overage preschool children is given in the table below:

\section{Table 1}

Socio-demographic Characteristics of Participants

\begin{tabular}{lccc}
\hline $\begin{array}{l}\text { Pseudo- } \\
\text { name }\end{array}$ & $\begin{array}{c}\text { Age } \\
\text { (in years) }\end{array}$ & Gender & Preschool Location \\
\hline Child A & 7 & Female & Rural \\
Child B & 8 & Male & Urban \\
Child C & 9 & Male & Urban \\
Child D & 7 & Male & Urban \\
Child E & 8 & Female & Rural \\
Child F & 8 & Female & Rural \\
Child G & 10 & Female & Urban \\
Child H & 9 & Male & Urban \\
Child I & 9 & Female & Rural \\
Child J & 7 & Male & Urban \\
Child K & 8 & Female & Rural \\
Child L & 10 & Male & Rural \\
\hline
\end{tabular}

This research focused mainly on overage children as the peculiarity of these individuals as becoming silenced and empirical research may not be able to reveal the reality of their. Of the three philosophical paradigms used in contemporary socio-scientific researches which are the positivist, interpretive and critical theory (Gage, 2007), the interpretive paradigm is considered to be ideal for this study as it allowed researchers to make an interpretation of what is seen, heard and understood from the submissions of the participants and not merely the preconceptions of the researcher.

The qualitative data collection adopted the phenomenological approach where the experiences of respondents and other features during the study were examined qualitatively. Qualitative data was collected using field notes, android phones which aided voice recordings as well as taking pictures to provide graphic illustrations for the study. This design was used to get verbal narratives from the children in a way that enables intense interaction between the researcher and the subject which is most likely possible in a qualitative study (Tracy, 2013).

To answer the research question, thematic approach of qualitative data analysis was adopted to present the findings from the interview schedule of research assistants in both the rural and urban areas. During the interview, the children gave several responses about their views on their preschool physical and emotional ambience. The interview, which lasted at an average of 12 minutes with each child, was recorded through voice recording devices such as midgets and android phones from where transcriptions were generated. The interview records 
were transposed into text and used as verbatim quotations. The views of the respondents as well as field note reports of the researcher were categorised based on the school environmental factors which were: resource availability, teacher-child relationship and peer interaction.

\section{Theme 1: Resources Availability}

The children interviewed expressed their views on the kinds of resources available in their schools. Most of them recounted that there were very few number of resources that suit them. For instance, when Child A, seven years old, from the selected rural pre-school was asked to talk about the things that are in her school, her response in Yoruba language was translated thus:

In my school, all of us use one big class where my brother and I use one bench to sit. We have pencils. We have a wall that 'mama' use to write on; we painted the wall last week with charcoal. During break, we can play in the class and we can play "sóbàtà" with our sandals. We have plenty trees but we do not play with them. Our own house is not far, so I go home when I want to toilet because my mother told me to be coming home to use the toilet because we don't have any toilet in my school.

When Child B, an eight years old, who was a boy from the urban pre-school was asked to also talk about things in his school, his claims were contrary to what Child A in the rural community said. He claimed that:

We have football that we play during break; we have that car thing that has steering and "Kúrú-maga" (See-Saw). We have a bowl where our aunty uses to wash the chalk in her hand. We also have where we buy food because they will not allow us buy something outside the gate. We have Pawpaw and Banana fruit beside the field fence. In our class, I have my own chair and we have toys in $A B C$ and 123. I do not use to paint but my brother use to.

However, it was reported by the research assistants in their field notes that the school had resources which were brought out when requested. For instance, the field note report of one of the research assistants in the urban pre-school, research assistant (RA1) stated thus:

Apart from the materials like globe that we saw at the Head-teacher's office, some other things were brought inside the class which the children were happy to use. An example was the brick alphabets and numbers. The teacher also showed us some colourful maps which the government just supplied them but they have not hanged them because they want to frame them so that it won't tear off soon. (Field Notes, November 2019)

Furthermore, the field note reported thus;

Most of the schools I visited today do not have any waste bin; in fact, where they dump their refuse is closer to their abandoned toilets. The toilet that I saw that is a bit okay, it was initially locked until they came to open it for me to see. I was told it is for the female teachers. (Field Notes, October 2019) 
It can be inferred from the submissions of both the interviews and field note report of the research assistants that there is scarce and uneven distribution of school resources in rural and urban pre-primary school centres of Ibadan.

\section{Theme 2:Teacher-Child Relationship}

The children interviewed had various views on how their teachers related with them in school. Some of the children at the preschools in rural area complained about the way their teachers related with them while those in the urban area had pleasant reports on how their teachers related with them.

For example, when asked how their teacher relates with them, Child C, a nine year old boy, who is from the urban preschool said:

My teacher use to play with us. She don't have cane in the class but if we do what is not good, she will call the person "atọọlé" (one who urinates on him/herself)

When Child D, seven years old, from the urban preschool was interviewed, he had a mixed view not too dissimilar about his teacher, the Child D said:

Uncle use to shout on me in the class but we use to play football together and if we play very well, Uncle will buy water for all of us, if we play rubbish, he will shout on us.

When children from the rural preschool were asked similar questions, one of those interviewed, Child E, a girl of 8 years said
Mama is very wicked, she use to send us away from her table if we want to go and weewee. Sometimes, she will beat all of us and say she cannot be helping us to read if our life does not know more than going to farm and eating alone.

A contrary view from Child $\mathrm{F}$, an 8 year old girl, who is also from the rural pre-primary school, is presented thus;
Anytime Uncle comes to our house, he used to greet my daddy very well because sometimes, he will sleep in our house and we will come to school together the second day. Uncle used to send me some things too that he will take along when travelling to the city where he lives.

The field note report of one of the research assistants in the urban community made some assertions. In the field note, research assistant (RA2) asserted that:

Some of the teachers were of a motherly age; most of them were just sitting down writing their notes. They gave less attention to the children except when we told them to engage the children in some activities, some of which took time before the children pick up. I observed that one of the teachers knows the children by their surname and has even gave them hilarious nick names like pansẹké, adárípọ́n and so on. (Field Notes, October 2019) 


\section{Theme 3: Peer-Interaction}

When the children were asked questions on what kind of recreational games they engaged in with their peers, the responses from the children in rural communities showed that the children loved to interact with each other very well. For example, when Child E, was asked the same question, she has this to say:

I am the only girl in the class but I used to play with Kazeem and Biyi. We use to play àrín together and we use to go home together.

Another response from Child A, from the rural pre-primary school was:

All of us play together in the classroom. All of them are my friends and they like me too.

However, when Child C was asked similar question, he said:

I play alone, I do not understand English very well and Aunty said I should not be speaking Yoruba with them. But aunty said anything I need, I should be asking her.

The field note report of one of the research assistants (RA3) in the urban community added to the submission thus:

The children seem to be doing fine, although, most of them were observed using their belongings to play on the table like more of a fantasy play. During break, the children interacted more with themselves than they were cold in the morning. (Field Note, October 2019)

\section{Discussion}

This study generally was aimed at putting together, the experiences and thoughts of overage children on the state of physical resources available and appropriate for them, teacherchild relationship and peer interaction in Ibadan preschools.

From the findings of this study, the qualitative data acquired from the children revealed that very little number of resources were available in their centres. The implication of this is that both in Ibadan urban and rural preschool centres, there is a limitation to resources the children have access to even though they may be available in some instances. This finding is buttressed by the submissions of Shaari and Ahmad (2016) who posited that there is no comprehensive physical learning environment assessment made by the government which has made the existing preschools' physical environment not evaluated for its 'fit for purpose' for children. Also, the status whether the provided infrastructures had fulfilled the children's unique demands and developmental needs, from children's view is unknown. This could be because most schools are still in the habit of hoarding some school resources from the use of children.

Further, children in rural pre-primary schools were of the view that their teachers do not interact with them so well while urban pre-primary schools children of Ibadan claimed that their teachers play with them as most of them also have nick names given to them by their teachers. The reason for this may be because teachers in urban preschool centres tend to have many channels of motivation such as income from extra-hour and private tutorials apart from the basic 
government remuneration. The view of the children is corroborated by the findings of Owoeye (2011), who found out in his study that most rural pre-school centres were managed by primary school teachers who showed less concern to the children.

Children in Ibadan rural pre-primary schools claimed they enjoyed playing with peers and doing things together unlike children in the urban communities who mostly played alone. This claim by the children may be pinned to the fact that, unlike the children in the rural communities, most of whom are forced to share whatever anyone has due to the scarcity of such thing(s), children in urban pre-primary schools mostly live independently as certain policies may have dictated that each child have his/her own belonging. The findings of Amosun (2019) were also similar to this who observed in a follow up study that overage children who have found themselves in pre-primary classes tend to be either selective in their choice of interaction and relationship.

This current research study has made an advancement in the field of research on the physical and emotional state of preschools in the specific view as majority of research about teacher-child relationships, peer interactions and school resources had focused on either underage or regular aged children. This research, however, investigated this issue as experienced by overage children which tends to enhance possible measures of inclusion in the education system and also suggests an implication for further early childhood education planners both locally and globally on the need to establish researches and generate policies that entails the place of overage children when exploring and employing developmentally appropriate practices. Although, there are time and collaboration induced limitations of this research to Ibadan, Nigeria alone, which accounts for just one of other Sub-Saharan Africa countries with overage children in education, development agencies could further push for a more encompassing study which would cover a wider geographical scope.

At the local level, this study recommends from its findings also that there is need for caregivers in preschool centres to improve in their relationship with overage children so as to foster free expression of thoughts and feelings from the child. Such improvement could be achieved through the way they pay attention to overage children's need regardless of individual differences. Similarly, pre-primary curriculum planners should endeavour to design contents aimed at encouraging more practises of socialization among children so that the consciousness of tolerating one another can be inculcated in early childhood, leading to pro-social behaviours.

\section{Conclusion}

Despite the plethora of trainings, researches and motivation (both material and immaterial) available within the reach of teachers in Ibadan, most of which would have informed them on what it takes to be a caregiver at the pre-primary level, it is still disheartening to find out that teachers at this level still make the aura of the classroom and school generally unfriendly for the children in through their relationship with overage children.

The finding of this study opened up the need for caregivers to be more welcoming in the manner in which they relate with overage children in preschools. On the one hand, this would require that caregivers be proactive and create an atmosphere whereby the children can feel free to play with and around them, and also to share their thoughts with them since teachers are meant to do their best in letting these children see them as in-loco parentis. On the other hand, government, stakeholders and school administrators will also need to introduce different kinds of motivations that will encourage teachers/caregivers in rural and urban communities to be positively disposed towards such children bearing in mind that every child is a child regardless of age. 


\section{Biographical Note}

Iyanuoluwa E. Olalowo is $\mathrm{PhD}$ student at the University of Ibadan, Nigeria where he earned a Master's degree in Early Childhood Education. He possesses pragmatic educational skills with certified experiences earned from world class universities including but not limited to Yale University. His research interest has been pitched around equity and equality in education, bridging the dichotomy between school aged children in marginalized communities and their counterparts in developing cities. He is currently conducting an Africa based phenomenological research on developmental negativity bias among African parents. He also reviews for the Journal of Early Childhood Association of Nigeria.

\section{References}

Advocates for Children of New York. (2008). Stuck in the middle: The problem of overage middle school students in New York City. Out of School Youth Coalition. http://www.advocatesforchildren.org/Stuck\%20in\%20the\%20Middle(final).pdf

Akpan, L. (2018). The Political undertone in the development of nomadic education in Africa: Lessons from Nigeria. American Journal of Qualitative Research, 2(1), 1-21.

Al-Badou, H., Al-Jamal, D., \& Sa'di, I. (2020). Language for Resilience: Semantic Mapping and Syrian Refugees. Journal of Ethnic and Cultural Studies, 7(1), 56-69. DOI: http://dx.doi.org/10.29333/ejecs/334

Amosun, M. D. (2012). School-based socio-metric variables and gender as predictors of primary school pupils 'attitude towards schooling and academic achievement (Doctoral thesis). University of Ibadan.

Amosun, M. D. (2019). Early childhood educators' awareness of and disposition to children's emotional wellbeing for life-long learning in Oyo state, Nigeria. In E. Oduolowu, I. A. Salami, \& M. D. Amosun (Eds.), Fundamentals of preschool and primary school teacher preparation in Nigeria education (pp. 276-288). Gab Educ. Printers.

Carothers, D., \& Parfitt, C. M. (2017). Disability or Language Difference: How Do We Decide?. American Journal of Qualitative Research, 1(1), 1-12.

Chepkonga, M. C. (2017). Influence of learning facilities on provision of quality education in early childhood development centres in Kenya. International Journal of Education \& Research, 5(6), 23-31.

Dallas Morning News. (2010, June 15). Editorial: Overage high school could help DISD curb dropout rate. The Dallas Morning News. https://www.dallasnews.com/opinion/editorials/2010/06/02/editorial-over-age-highschool-could-help-disd-curb-dropout-rate/

Darvas P. \& Namit, K. (2016, November 14). How do you solve a problem like over-age enrolment? World Bank Blogs. https://blogs.worldbank.org/education/how-do-yousolve-problem-over-age-enrolment

Ezewu, E.E. (1986). Sociology of Education. Harlow. Pearson Education Limited

Fast Track Initiative. (2013). Education for all: Fast track initiative endorsement report: Lesotho. Global Partnership for https://www.globalpartnership.org/sites/default/files/2013-07-FTI-EndorsementAssessment-Lesotho_processed.pdf

Federal Republic of Nigeria. (2013). National policy on education (6th ed.). NERDC Press.

Gage, N. (2007). The paradigm wars and their aftermath: A historical sketch of research on teaching since 1989. In M. Hammersley (Ed.), Educational research and evidencebased practice (pp. 151-166). SAGE. 
Garner, P. W., Mahatmya, D., Moses, L. K., \& Bolt, E. N. (2014). Associations of preschool type and teacher-child relational quality with young children's social-emotional competence. Early Education \& Development, 25(3), 399-420.

Gumus, O. D., Yalcinkaya, T., \& Kayaalp, A. (2019). Psychology of Turkish University Students as Electorate: The Mediating Role of Political Trust. Journal of Ethnic and Cultural Studies, 6(1), 45-62. DOI: http://dx.doi.org/10.29333/ejecs/180

Hamre, B., Hatfield, B., Pianta, R., \& Jamil, F. (2014). Evidence for general and domain specific elements of teacher-child interactions: Associations with preschool children's development. Child development, 85(3), 1257-1274.

Henning, M., Kirk, C. M., Franchett, E., Wilder, R., Sezibera, V., Ukundineza, \& Betancourt, T. (2018). Over-age and underserved: A case-control study of HIV-affected children and education in Rwanda. Vulnurable Children \& Youth Studies, 13(1), 81-93.

Kaliska, L., \& Akbey, B. (2019). Post-traumatic Stress Disorder Related to Trait Emotional Intelligence of Slovaks in Comparison to Turkish Immigrants in Slovakia. Journal of Ethnic and Cultural Studies, 6(3), 147-157. DOI: http://dx.doi.org/10.29333/ejecs/283

Knevals, J. (2014). Operationalizing the definition of over-age and under-credit students in alternative campuses. Journal of Colorado Department of Education 1(3), 1-14.

Mantzicopoulos, P., French, B. F., Patrick, H., Watson, J. S., \& Ahn, I. (2018). The stability of kindergarten teachers' effectiveness: A generalizability study comparing the Framework for Teaching and the Classroom Assessment Scoring System. Educational Assessment, 23(1), 24-46.

McGuey, G., \& Moore, L. (2016). The inspirational teacher. Routledge.

Oduolowu, E., Salami, I. A., \& Amosun, M. D. (Eds.). (2019). Fundamentals of preschool and primary school teacher preparation in Nigeria education in Nigeria: A Book of readings (preface). Gab Educ. Printers.

Owoeye, J. S. (2011). School location and academic achievement of secondary school in Ekiti state, Nigeria. Asian Social Science, 7(5), 170-175.

Pennings, H. J., Brekelmans, M., Sadler, P., Claessens, L. C., van der Want, A. C., \& van Tartwijk, J. (2018). Interpersonal adaptation in teacher-student interaction. Learning and Instruction, 55, 41-57.

Salami, I. A. (2016). Nigerian early childhood education policies and practices for sustainability. European Journal of Research and Reflection in Educational Sciences 4(5), 71-85.

Salami, I. A. (2018, July 23-27). Nigeria Transition from developing to developed nation: How possible without effective, functional and equal access to quality Early childhood education? [Lead Paper presentation]. National Conference of Early Childhood Association of Nigeria (ECAN), Zuba, Abuja.

Salami, I. A., \& Folaranmi, F. F. (2015). Teaching practices in lower primary classes in Abeokuta north of Ogun State, Nigeria: The contributions of teacher variables. International Journal of Innovative Education Research 3(2), 39-47.

SECC. (2008). Rapid response - Educating overage students. Southeast Comprehensive Centre. https://sedl.org/secc/orc/rr/secc_rr_00078.pdf

Shaari, M. F., \& Ahmad, S. S. (2016). Physical learning environment: Impact on children school readiness in Africa preschools. Procedia - Social and Behavioral Sciences, 222(2016), 9-18. https://doi.org/10.1016/j.sbspro.2016.05.164

Sjoman, M. (2018). Peer interaction in preschool: Necessary, but not sufficient - The influence of social interaction on the link between behaviour difficulties and engagement among children with and without need of special support [Doctoral thesis]. Jonkoping University.

Tracy, S. J. (2013). Qualitative research methods; a collecting evidence, crafting analysis, communicating impact. Wiley-Blackwell. 
UK Department for Education. (2017). Statutory framework for the early years foundation stage. Crown.

UNESCO (2012). International Standard Classification of Education 2011. Canada. UNESCO Institute for Statistics.

Manuscript received May 26, 2020

Final revision received June 20, 2020

Accepted July 05, 2020 